\title{
Perancangan Sistem Informasi Open Data Pada Industri Kecil dan Menengah Kota Padang Berbasis Web
}

\section{Design of Information System of Open Data on Small and Medium-sized Industrial City of Padang Web Based}

\author{
Junaldi $^{1)}$, Hidra Amnur ${ }^{2)} \&$ Defni $^{2)}$ \\ ${ }^{1)}$ Jurusan Elektro Politeknik Negeri Padang Kampus Limau Manis Padang 25163 \\ Telp 0751-72590 Fax 0752-72576 \\ ${ }^{2)}$ Jurusan Teknologi Informasi, Politeknik Negeri Padang Kampus Limau Manis Padang 25163 \\ Telp 0751-72590 Fax 0752-72576 Email : defni.devan@ gmail.com
}

\begin{abstract}
Padang society known as people who have the spirit of entrepreneurship, it is marked by the increasing number of small and medium industries in the city of Padang. Limitations of this information gives the impression of small and medium industries that runs itself. This article will produce a product web-based information system that is open data is the latest in the field of information technology. This information system will as a place for people to obtain information data in the form of products, the location of the small and medium industrial enterprises in the city of Padang. This information system also can be used as a medium for the industry small and medium enterprises in the city of Padang to obtain information
\end{abstract}

Keywords : Small and Medium Industrial, Open Data, Information System, Web

\section{PENDAHULUAN}

Di Indonesia, dunia industri kecil dan menengah memegang peranan yang sangat penting dalam sistem perekonomian Indonesia. Di dalam perekonomian nasional, industri kecil dan menengah dapat memberikan kontribusi dalam peningkatan perekonomian seperti peningkatan kesempatan kerja, pemerataan pendapatan, akselerasi perekonomian di pedesaan, peningkatan ekspor non migas dan peningkatan di sektor perekonomian lainnya. Di kota Padang, industri kecil dan menengah ini juga mampu menyerap banyak lapangan pekerjaan. Berdasarkan data yang di dapatkan pada dinas perindustrian perdagangan pertambangan dan energy kota Padang tepatnya pada bidang industri kecil dan menengah kota padangyang dilakukan pada tahun 2014, pelaku industri kecil dan menengah ini dikelompokan menjadi 5 kelompok yaitu : industri kecil dan menengah potensi pangan dengan jumlah 1.127 unit sementara jumlah tenaga kerja yang terserap yaitu 3.743 orang, industri kecil dan menengah potensi sandang kulit dengan jumlah 298 unit sedangkan jumlah serapan tenaga kerja yaitu 1.186 orang pekerja, industri kecil dan menengah potensi kimia dan bahan bangunan berjumlah 399 unit dengan serapan tenaga kerja yaitu 2.548 orang, industri kecil dan menengah potensi logam dan elektronika berjumlah 163 dengan serapan tenaga kerja 668 orang, industri kecil dan menengah potensi kerajian dengan jumlah 91 unit dan serapan tenaga kerja yaitu 446 orang. Jadi, jika di totalkan jumlah industri kecil dan menegah yang ada di kota padang yaitu 2.078 unit dan mampu menyerap tenaga kerja sejumlah 8.591 orang.

Berdasarkan pendapat Tambunan dimana industri kecil dan menegah ini memiliki kelemahan yang disebut dengan kelemahan kultural. Kelemahan kultural 
mengakibatkan kurangnya akses informasi dan lemahnya berbagai persyaratan lain guna memperoleh info rm a si, seperti : informasi peluang dan tata cara memasarkan produk, informasi untuk mendapatkan bahan baku yang baik, murah, dan mudah didapat, informasi untuk memperoleh fasilitas dan bantuan pengusaha besar dalam menjalin hubungan kemitraan untuk memperoleh bantuan permodalan dan pemasaran, informasi tentang tata cara pengembangan produk, baik desain, kualitas, maupun kemasannya, informasi untuk menambah sumber permodalan dengan persyaratan yang terjangkau (emrizal, 2013) .

Akses informasi secara cepat dan tepat merupakan salah satu tahap yang penting untuk diterapkan dalam rangka inisiatif pembangunan secara global begitu juga dalam sector industri kecil dan menengah. Hal ini didukung dengan kemajuan teknologi yang mengharuskan pemerintah untuk dapat melakukan perubahan secara mendalam terhadap perangkat teknologi informasi tepatnya pada sistem informasi, terkhusus kepada data pemerintah yang mendukung pembanguan ekonomi tersebut. Kesenjangan penyebaran informasi akan dapat melahirkan dampak terhadap pelaksanaan pembangunan, karena hanya segelintir orang yang dapat merasakan pembagunan dengan akses terhadap informasi yang mendukung. Saat ini, pemerintah Indonesia memiliki kecenderungan aktif untuk melaksanakan gerakan Open Government Partnership (OGP), sebuah insiatif internasional yang mendorong pemerintah untuk berkolaboratif dan terbuka dengan masyarakat, dalam hal ini menyangkut kebijakan transparansi informasi (www.kompas. com). Untuk dapat melakukan kebijakan transformasi informasi ini maka pemerintah pusat dan daerah sedang gencar melakukan perubahan sistem informasinya agar tercipta suatu pemerintahan yang transparan, akuntabilitas serta akuntabel. Salah satu kebijakan perubahan di bidang sistem informasi yang dilakukan oleh pemerintahan pusat dan daerah adalah dengan menerapkan kebijakan data terbuka atau open data yang berbasiskan akses informasi yang terbuka untuk setiap masyarakat untuk dapat digunakan oleh masyarakat tersebut. Kebijakan tersebut dipandang mampu mendorong terciptanya pemerintahan yang terbuka, transparan, serta akuntabel untuk membantu proses pembangunan di suatu daerah dan dalam rangka meningkatkan pelayanan public kepada masayarakatnya.

Berpotensinya industri kecil dan menengah yang ada di kota padang ini masih terkesan jalan sendiri hal ini disebabkan oleh kurangnya akses informasi yang di dapatkan oleh pelaku industri kecil dan menengah ini. Fenomena gerakan Open Government Partnertship (OGP) yang di canangkan oleh pemerintah seharusnya di jadikan momentum untuk mengatasi keterbatasan akses informasi yang dihadapi oleh pihak pelaku industri kecil dan menengah di kota padang dapat berkembang dengan baik sehingga Kelemahan kultural dapat teratasi. Dengan adanya gerakan OGP ini yang menjadikan data terbuka sebagai pilarnya dapat dimamfaatkan oleh pelaku industri kecil dan menengah yang ada di kota Padang. Selain itu data terbuka ini dapat dijadikan sebagai sarana promosi maupun pendataan dari industri kecil dan menengah itu sendiri yang dapat meningkatkan pendapatan dari para pelaku usaha tersebut. Open data dalam bentuk sistem informasi ini nantinya dapat juga dimamfaatkan oleh masyarakat untuk mengetahui tentang industri kecil dan menengah yang ada di kota Padang, seperti lokasi, produk dan jumlah tenaga kerjanya. Sistem ini juga dapat membantu pemerintah dalam pendataan yang baik dari pelaku industri kecil dan menengah dan dapat mendatangkan investor untuk menanamkan modalnya kepada industri kecil dan menengah yang ada di kota Padang. Tujuan dalam penelitian ini adalah :

a. Membuat sebuah sistem informasi yang 
berbasiskan open data atau data terbuka tentang data-data industri kecil dan menengah yang ada di kota Padang yang dapat dijadikan sebagai tempat informasi bagi masyarakat untuk mendapatkan data-data berupa produk, lokasi dari industri kecil dan menengah yang ada di kota Padang.

b. Membuat sebuah sistem informasi yang berbasiskan open data atau data terbuka tentang data-data industri kecil dan menengah yang ada di kota Padang sehingga dapat dijadikan sebagai media untuk mendapatkan informasi tentang peluang dan tata cara memasarkan produk, informasi untuk mendapatkan bahan baku yang baik, murah, dan mudah didapat, informasi untuk memperoleh fasilitas dan bantuan pengusaha besar dalam menjalin hubungan kemitraan untuk memperoleh bantuan permodalan dan pemasaran.

c. Membuat sebuah sistem informasi yang dapat dijadikan sebagai media promosi bagi pelaku industri kecil dan menengah yang ada di kota Padang, hal ini dapat menambah pendapatan bagi para pelaku industri kecil dan menengah di Kota padang dan dapat mendatangkan investasi bagi penanam modal untuk dapat menanamkan modalnya di kota Padang.

d. Membuat sebuah aplikasi open data atau data terbuka tentang data-data industri kecil dan menengah yang ada di kota Padang untuk mewujudkan kota Padang menuju gerakan Open Government Partnership (OGP) yaitu suatu gerakan untuk menjadikan pemerintah merupakan partner dari masyarakat dan data-data pemerintahan terbuka dan bisa di akses oleh masyarakat.

e. Keluaran dari sistem informasi data terbuka atau open data ini nantinya akan dipublikasikan di jurnal national.

\section{Pengertian Open data atau data terbuka}

Sejak tahun 2009, open data mulai dikenal setelah beberapa pemerintah (misalnya pemerintah AS, Inggris,
Kanada, dan Selandia Baru) mengumumkan inisiatif baru yang mengarah pada pembukaan informasi publik. Open data atau data terbuka ialah informasi yang tersedia bebas untuk siapa saja, dimana saja untuk digunakan dan dipergunakan kembali. Data dikatakan sepenuhnya terbuka apabila tidak ada batasan dalam penggunaannya dalam ranah publik, privat, penelitian nirlaba, atau bahkan ketika digunakan ke dalam aplikasi komersial.

Banyak orang dan organisasi mencari dan mengumpulkan berbagai jenis data untuk mengerjakan tugas mereka. Dalam hal ini, peran pemerintah sangat signifikan, bukan hanya karena kuantitas dan sentralitas data yang dikumpulkannnya, melainkan juga karena menurut hukum, data pemerintah pada umumnya adalah data publik, sehingga harus dibuka dan bisa digunakan oleh yang lain. Pada banyak bidang, keberadaan open data akan berharga.Ada kelompok dan organisasi yang mendapat manfaat dari ketersediaan open data, termasuk pemerintah sendiri.

Hal yang terpenting dari open data atau data terbuka adalah :

1. Ketersediaan dan Akses: data harus tersedia utuh dan tidak memerlukan biaya reproduksi yang berlebihan, lebih disarankan jika data bisa diunduh dari internet. Data juga harus tersedia dalam bentuk yang mudah digunakan (convenient) dan dapat diubah (modifiable).

2. Penggunaan kembali dan penyebarluasan kembali data harus dilakukan melalui syarat-syarat yang berlaku bagi penggunaan-kembali dan penyebarluasan-kembali,termasuk pencampuran dengan set data lain.

3. Partisipasi Universal : setiap orang bisa menggunakan, menggunakan kembali, dan menyebarluaskan kembali tidak boleh ada diskriminasi atas bidang usaha, orang, atau kelompok.

\section{Ekosistem open data}

Open Data, khususnya Open 
Government Data, pada dasarnya bertujuan menyediakan data atau informasi yang dapat digunakan oleh user (masyarakat, NGO, peneliti, konsumen, dll) untuk memenuhi kebutuhannya. Proses penyampaian informasi dari penyedia data ke user terjadi melalui suatu ekosistem tertentu.

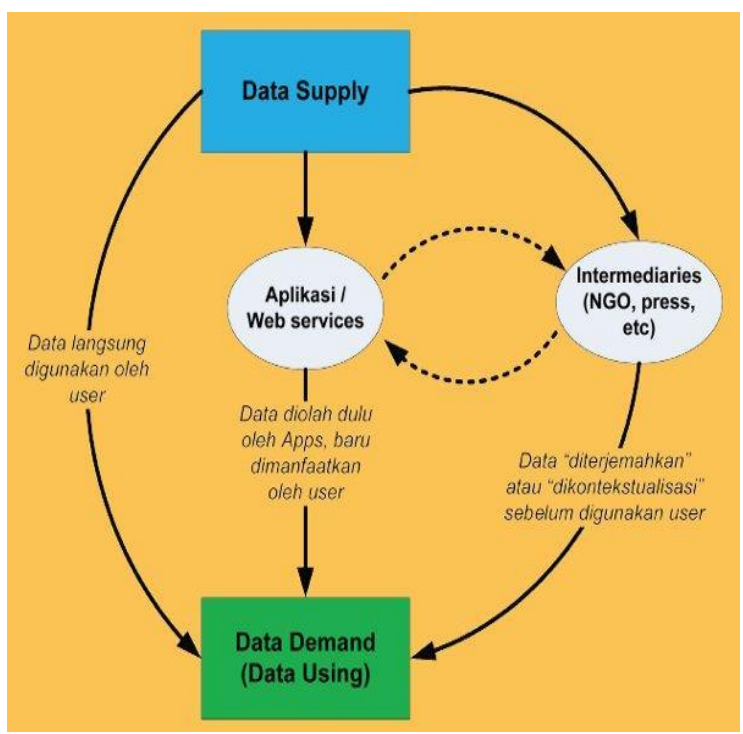

Gambar 1. Ekosistem open data ( sinergi, 2013)

Ekosisem itu disebut "Ekosistem Open Data". Dalam hal ini, data yang disediakan oleh pemerintah ketika dibuka ke publik, tidak semuanya dapat langsung dimanfaatkan oleh masyarakat atau pengguna lainnya. Sebagian data baru bermanfaat jika telah diolah oleh aplikasiaplikasi di web. Sebagian data lainnya baru bermanfaat ketika data tersebut telah "diterjemahkan". Aplikasiaplikasi di web yang dimaksud (web services) biasanya merupakan layanan yang dibangun oleh masyarakat atau oleh perusahaan komersial. Contoh aplikasi adalah google maps, Sedangkan intermediaries dalam ekosistem open data ini biasanya adalah NGO, media massa, aktivis IT atau perusahan yang secara volounteer maupun komersial berkepentingan untuk mejadikan informasi atau data di pemerintah dapat dimanfaatkan oleh user. Intermediaries seringkali juga memamfaatkan Apps yang ada di web, bukan langsung mengambil dari data source di pemerintah langsung.

Proses translasi atau penterjemah adalah mulai dari membawakan data dari bentuk digital ke dalam bentuk tercetak, hingga mengolah ulang data sehingga masyarakat dapat menggunakan data itu sesuai kepentingan dan latar belakang pengetahuannya. Misalnya adalah proses bagaimana menyampaikan informasi tentang pertanian (situsasi pasar komoditas, kebijakan pertanian, data iklim, perkembangan teknologi pertanian, dsb) kepada petani di desa terpencil.

Pada prinsipnya open data government ini dapat berlangsung jika terdapat :

1. Transparansi (transparency) yaitu menyediakan data dan informasi kepada publik tentang semua kegiatan pemerintah. Dengan premis transparansi, negara wajib menjamin hak tiap warga negara untuk mengetahui apa, bagaimana, dan mengapa pemerintah memutuskan atau menjalankan suatu kebijakan.

2. Partisipasi (participation) suara warga negara dalam urusan publik. Pejabat publik akan memperoleh manfaat dari perspektif ahli atau non-ahli yang berada di luar pemerintahan. Partisipasi memperluas kesempatan warga negara untuk mengekspresikan pandangan mereka tentang alternatif kebijakan.

3. Kolaborasi (collaboration) artinya Kolaborasi mengikis "kita-lawanmereka" yang membagi antara warga dan pemerintah. Warga dapat menggarap secara bersama agenda pemerintah. Mereka juga dapat bantu menentukan cara dan metodenya. Dalam kolaborasi, warga merupakan mitra pemerintah.

\section{Industri Kecil dan Menengah}

Usaha pembangunan yang sedang giat dilaksanakan oleh negara-negara sedang berkembang (Developing Countries) di dunia, pada umumnya berorientasi pada cara memperbaiki serta mengangkat tingkat hidup masyarakat. 
Pembangunan ekonomi merupakan jawaban bagi keberhasilan suatu negara untuk meningkatkan taraf hidup masyarakatnya. Indonesia merupakan negara yang sedang berkembang yang sedang berusaha meningkatkan perekonomian nasional guna meningkatkan kesejahteraan masyarakatnya.

Dalam perekonomian Indonesia dunia usaha merupakan bagian yang sangat penting dalam meningkatkan laju pertumbuhan ekonomi. Industri kecil dan menengah (IKM) yang merupakan bagian dari dunia usaha, memegang peranan yang sangat penting dalam sistem perekonomian Indonesia. Oleh karena dalam perekonomian nasional IKM dapat memberikan kontribusi dalam peningkatan perekonomian seperti peningkatan kesempatan kerja, pemerataan pendapatan, akselerasi perekonomian di pedesaan, peningkatan ekspor non migas dan peningkatan di sektor perekonomian lainnya (emrizal, 2013).

Industri kecil dan menengah (IKM) adalah jenis usaha yang paling banyak jumlahnya di Indonesia, tetapi saat ini batasan mengenai kriteria usaha mikro dan kecil di Indonesia masih beragam. Pengertian kecil dalam usaha kecil bersifat relatif, sehingga perlu ada batasan yang dapat menimbulkan definisi-definisi usaha kecil dari berbagai segi.

Adapun Karakteristik Industri dari industri kecil dan menengah adalah :

1. Padat karya.

Dengan sifatnya yang padat karya sehingga industri kecil dapat menyerap banyak tenaga kerja, kghususnya tenaga kerja daerah, sehingga dapat mengurangi tingkat pengangguran dalam kondisi pertambahan penduduk yang cukup tinggi sedangkan lapangan kerja terbatas sekali, maka kegiatan- kegiatan yang mampu menyerap tenaga kerja mempunyai peran penting.

2. Modal kecil.

Mayoritas usaha kecil memiliki modal yang relatif kecil. Faktor yang menyebabkan kecilnya modal yang dimiliki oleh sector usaha kecil adalah karena modalnya bersumber dari keuangan pribadi. Factor yang kedua adalah banyaknya persyaratan yang harus dipenuhi apabila mengajukan permohonan kepada pihak Bank.

3. Teknologi sederhana.

Teknologi yang digunakan dalam usaha kecil biasanya bersifat konvensional. Penggunaan teknologi konvensional ini selain disebabkan oleh minimnya dana, tapi juga karena proses produksinya tidak membutuhkan teknologi tinggi.

4. Pemerataan.

Sifatnya sesuai dengan kondisi daerah maka Industri Kecil dapat dikembangkan di daerah.

5. Fungsi dan Peran IKM

IKM (industri Kecil dan Menengah) memiliki peran yang sangat besar terhadap perekonomian nasional. Adapun fungsi dan peran IKM diantaranya adalah sebagai: penyedia barang dan jasa, penyerap teanaga kerja, pemerataan pendapatan, nilai tambah bagi produk daerah, peningkatan taraf hidup. Melihat perannya yang begitu besar maka pembinaan dan pengembangan industri kecil bukan saja penting sebagai jalur ke arah pemerataan hasil-hasil pembangunan, tetapi juga sebagai unsur pokok dari seluruh struktur industri di Indonesia, karena dengan investasi yang kecil dapat berproduksi secara efektif dan dapat menyerap banyak tenaga kerja.

\section{Kota Padang terdiri dari 11} kecamatan dengan luas wilayah keseluruhan sejumlah 694,96 km2. Kecamatan dengan luas wilayah terbesar yaitu wilayah Kecamatan Koto Tengah $(232,25 \mathrm{~km} 2)$ atau sepertiga luas wilayah Kota Padang dan wilayah kecamatan dengan luas terkecil yaitu Kecamatan Padang Barat $(7 \mathrm{~km} 2)$. Dari data sensus penduduk tahun 2010, jumlah penduduk 
Kota Padang yaitu sejumlah 765.450 jiwa. Wilayah dengan jumlah penduduk terbesar yaitu Kecamatan Koto Tengah (141.638 jiwa), kemudian disusul Kecamatan Kuranci (105.370 jiwa) dan Lubuk Begalung (93.203 jiwa). Sedangkan wilayah kecamatan dengan jumlah penduduk terkecil yaitu Kecamatan Bungus Teluk Bungus (22.164 jiwa). Kepadatan penduduk rata-rata Kota Padang pada tahun yang sama, yaitu sebesar 1.101 jiwa $/ \mathrm{km} 2$. Kecamatan dengan rata-rata kepadatan tinggi yaitu terutama pada bagian pusat kota, yakni Kota Lama yaitu Kecamatan Padang Timur (9.744 jiwa/km2), Padang Utara (8.599 jiwa/m2), Padang Barat (8.140 jiwa/km2). Sedangkan wilayah kecamatan yang lain mempunyai rata-rata kepadatan penduduk yaitu Kecamatan Bungus Teluk Bangus (220 jiwa/km2), Pauh (1.546 jiwa/km2)( http ://padang.go.id ) dan ( biro pusat statistik tahun 2009).

Masyarakat Padang sendiri terkenal dengan masyarakat yang mempunyai jiwa "berdagang" atau berwirausaha sehingga banyak anggota masyarakat yang memiliki pekerjaan berwirausaha. Hal ini ditunjukan dengan data jumlah industri kecil dan menengah dikota Padang itu sangat banyak dan meningkat terus dari tahun ke tahun.

Dinas perindustrian perdagangan pertambangan dan energy kota Padang membedakan Industri kecil dan menengah di kota Padang menjadi 5 bagian yaitu :

1. Industri kecil dan menengah potensi pangan

2. Industri kecil dan menengah potensi sandang kulit

3. Industri kecil dan menengah potensi kimia dan bahan bangunan

4. Industri kecil dan menengah potensi logam dan elektronika

5. Industri kecil dan menengah potensi kerajinan kota padang

Table berikut ini menggambarkan jumlah unit dan jumlah tenaga kerja yang di serap masing- masing industri kecil dan menengah berdasarkan data yang di dapatkan dari dinas perindustrian perdagangan pertambangan dan energy kota Padang hasil sensus 2014 seperti yang ada pada

lampiran.

\section{Model Spiral}

Siklus hidup yang paling terkenal dalam dunia RPL adalah waterfall model Waterfall model diciptakan pertama kali oleh William Royce pada tahun 1970 dan mulai terkenal karena logika fase (tahapan,tingkatan,masa). Waterfall sendiri memiliki definisi bahwa sebuah proses hidup perangkat lunak memiliki proses yang linier dan sequensial.

Model spiral merupakan kombinasi antara model iterative dan model linear seperti waterfall yang dititik beratkan pada evaluasi analisis resiko. Model spiral terdiri atas lima tahapan. Dalam pembangunannya, sistem informasi atau perangkat lunak yang dibanggun secara iterasi melewati lima tahapan tersebut.

Tahapan-tahapan tersebut adalah Gambar 2.

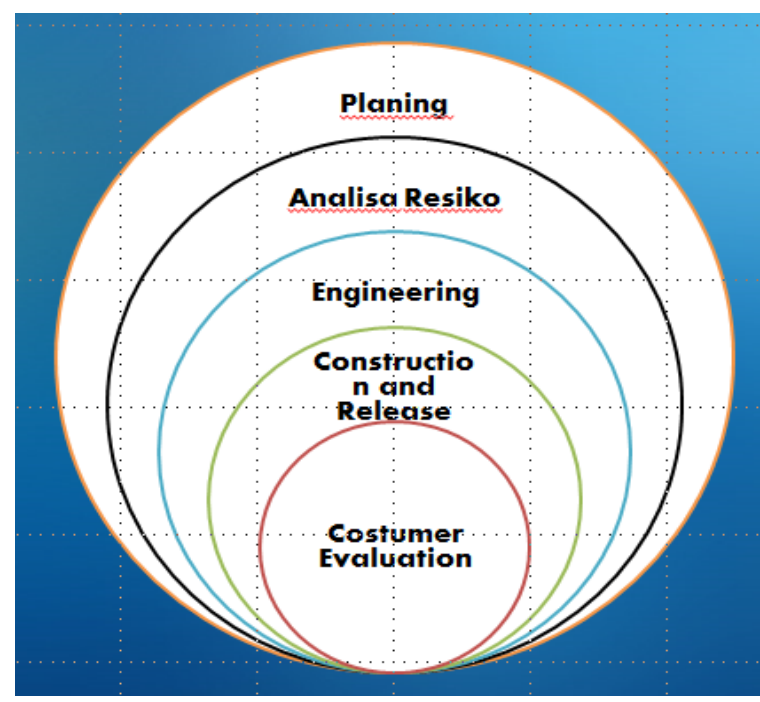

Gambar 2. Model Spiral

Adapun tahapan-tahapan tersebut adalah :

1. Planning : perencanaan dari perangkat lunak itu sendiri ( waktu pengerjaan, sumber daya yang dibutuhkan, informasi yang menyangkut pengerjaan proyek). Tahapan ini dimulai dengan mengumpulkan kebutuhan-kebutuhan 
bisnis sebagai dasar dari spiral. Selanjutnya seiring dengan pengembangan produk, identifikasi kebutuhan sistem, serta kebutuhan sub sistem dilakukan pada tahap ini. Pemahaman kebutuhan sistem dilakukan dengan komunikasi terus menerus antara konsumen dan analis sistem.

2. Analisa Resiko : resiko yang mungkin terjadi baik secara teknik maupun secara manejerial.

3. Engineering : pembuatan dari perangkat lunak itu sendiri. Tahap enginnering dimulai engan membuat desain konseptual sebagai dasar dari spiralnya. Desain konseptual ini termasuk desain arsitektur, desain modul, desain sistem, dan desain akhir.

4. Construction and Release : perangkat lunak telah siap diinstalasikan ke pengguna. Tahap con stru ction mengacu pada pembuatan perangkat lunak yang sebenarnya. Pada tahap ini, hasil-hasil yang didapatkan dari fase perancangan diimplementasikan kedalam sebuah produk yang akan digunakan oleh konsumen. Pembangunan produk ini juga dikomunikasikan dengan konsumen untuk mengetahui apakah produk yang dibuat sesuai dengan keinginan konsumen.

5. Costumer Evaluation : adanya umpan balik dari pengguna sekaligus sebagai dasar untuk pengembangan perangkat lunak berikutnya. Analisis resiko meliputi identifikasi, estimasi, dan monitoring kemampuan teknis serta manajemen resiko seperti penjadwalan yang salah maupun biaya yang melebihi estimasi awal. Setelah produk yang dibuat diuji, pada akhir iterasi spiral, konsumen melakukan evaluasi terhadap perangkat lunak dan memberikan umpan balik kepada pengembang.

Berdasarkan evaluasi konsumen ini, proses pengembangan perangkat lunak memasuki iterasi berikutnya pada model spiral dan menggunakan pendekatan linear untuk mengimplementasikan saran-saran konsumen.

Model spiral cocok digunakan untuk pengembangan perangkat lunak berikut :

1. Ketika ada batasan biaya dan evaluasi serta analisis resiko merupakan salah satu factor penting

2. Digunakan untuk proyek pengembangan dengan resiko menengah sampai besar

3. Untuk proyek dengan jangka waktu panjang karena adanya potensi perubahan prioritas ekonomi yang sejalan dengan perubahan kebutuhan system

4. Konsumen yang tidak yakin mengenai kebutuhan sistem yang akan dibuat. Kebutuhan sistem cukup kompleks sehingga membutuhkan evaluasi untuk memperjelasnya.

\section{Metode dan Perancangan}

Penelitian ini dirancang untuk dapat dilaksanakan selama dua tahun. Pada tahun pertama pembangunan sistem informasi data terbuka berbasis Web dengan menggunakan PHP dan MySQL. Pada Tahun kedua sistem informasi data terbuka ini dikembangkan untuk dapat dipergunakan oleh perangkat mobile dengan menggunakan sistem operasi berbasis android.

Sesuai siklus hidup dari sistem informasi pada penelitian ini akan menggunakan model Spiral, fase-fase yang akan dilakukan pada penelitian ini sesuai dengan model spiral pada siklus hidup sistem informasi adalah:

\section{1) Planning}

Tahap perencanaan dimulai dengan cara mengumpulkan data primer dan data sekunder . Data primer merupakan datadata yang di dapatkan dari dinas perindustrian perdagangan pertambangan dan energi kota Padang bidang industri kecil dan menengah serta dengan mengumpulkan data-data yang di dapat dari hasil biro pusat statistic kota Padang, 
sementara data- data sekunder di dapatkan dari pelaku industri kecil dan menengah berdasarkan kelompok potensi industri kecil dan menengah. Hal-hal yang dilakukan dalam tahapan Planning ini diantaranya :

a. Pengamatan (Observasi )

Pengamatan telah dilakukan sebelum membuat proposal penelitian dengan cara mendatangi objek penelitian dan melakukan pencatatan sebagai penelitian pendahuluan yang tujuannya untuk validasi dalam mengajukan proposal penelitian.

b. Wawancara (Interview)

Wawancara dilakukan terhadap pengelola unit usaha industri kecil yang ada di Kota Padang untuk memperoleh informasi tentang kondisi usaha, strategi pemasaran yang selama ini dilakukan, dan mengidentifikasi kondisi lingkungan internal serta lingkungan eksternal yang dihadapi unit-unit usaha industri kecil dan menengah di Kota Padang. Wawancara dilakukan dengan dinas perindustrian perdagangan pertambangan dan energy kota padang tepatnya wawancara dilakukan dengan sekretaris dinas perindustrian perdagangan pertambangan dan energy tepatnya pada bidang industri kecil dan menengah dari hasil wawancara di dapatkan bahwa selama ini bidang industri kecil dan menengah ini mengalami kesulitan dalam mendata industri ini karena belum ada tempat penyimpanan data yang baik sehingga ketika ada permasalahan tentang industri kecil dan menengah akan kesulitan dalam mengambil kebijakan terhadap industri kecil dan menengah tersebut, untuk mendapatkan data sekunder dilakukan dengan mendatangkan industri kecil dan menengah dengan memberikan pertanyaan-pertanyaan yang terstruktur yang disusun dalam bentuk sebuah kuisioner/angket. Dimana responden dipandu untuk mengisi datadatanya seperti nama usaha,alamat, fax, cara mendapatkan modal, cara pemasaran, cara mendapatkan bahan baku dan lain sebagainya.

\section{2) Analisis Resiko}

Tahapan analisis resiko dilakukan dengan cara membandingkan data-data yang di dapat, dan mulai memilah datadata yang diperlukan untuk penelitian. Tahapan analisis resiko juga menjelaskan keuntungan yang di dapatkan dari penelitian yang dilakukan kepada para pelaku industri kecil dan menengah yang ada di kota Padang.

\section{3) Enginnering}

Berdasarkan hasil analisis, pada bagian ini dilakukan perancangan sistem informasi yang meliputi :

a. Perancangan arsitektur sistem dengan menggambarkan aliran data antar proses- proses yang terjadi dalam sistem menggunakan Data Flow Diagram (DFD)

b. Perancangan basis data dengan menggambarkan keterhubungan antar entitas menggunakan Entity Relationship Diagram (ERD) dan Relational Diagram.

c. Perancangan antar muka sistem informasi d. Perancangan fungsionalitas dan alur sistem informasi

Hasil rancangan ini akan kembali dikomunikasikan dengan pihak dinas perindustrian perdagangan pertambangan dan energy terutama bidang industri kecil dan menengah di kota Padang, untuk diperiksa apakah telah sesuai dengan kebutuhan sistem dan untuk mereview kembali apakah pemahaman peneliti terhadap proses bisnis yang berjalan sesuai dengan yang dijabarkah sebelumnya dan sesuai dengan kebutuhan user.

\section{4) Construction and Release}

Setelah proses rancangan selesai, Sistem Informasi open data industri k ecil dan menengah ini mulai dibangun. Karena sistem ini dibangun berbasis web, maka pembangunan sistem dilakukan menggunakan bahasa pemrograman HTML5, PHP dikombinasikan dengan Javascript dan CSS serta menggunakan MySQL untuk pengolahan basis datanya. Selama masa pembangunan sistem, 
pengujian terhadap fungsionalitas sistem informasi ini akan terus dilakukan baik menggunakan data dummy maupun data asli yang didapatkan dari data primer dan data sekunder.

Pada tahap ini juga dilakukan proses pengumpulan data yang diperlukan untuk tiap sistem informasi sehingga sistem yang dibangun dapat langsung diuji dengan data sebenarnya. Pengujian menggunakan data asli (real data) sangat penting untuk mengetahui tingkat kebenaran seluruh fungsionalitas yang melibatkan data tersebut.

Jika seluruh tahap pembangunan selesai dan semua fungsionalitas sistem telah lulus uji, implementasi sistem informasi dilakukan di dinas perindustrian perdagangan pertambangan dan energy kota Padang tepatnya pada bidang industri kecil dan menengah. Untuk kemanan data dan kemudahan implementasi serta perawatan sistem, pada dinas perindustrian perdagangan pertambangan dan energy kota Padang tepatnya pada bidang industri kecil dan menengah akan ada server komputer dimana sistem ini akan ditempatkan. Implementasi sistem informasi ini juga diikuti dengan pelatihan penggunaan sistem untuk pegawai yang bekerja di dinas perindustrian perdagangan pertambangan dan energy kota Padang tepatnya pada bidang industri kecil dan menengah yang nanti pegawainya akan mengelola sistem informasi ini.

\section{5) Costumer Evaluation}

Setelah sistem informasi diimplementasikan dan dijalankan di dinas perindustrian perdagangan pertambangan dan energi terutama pada bidang industri kecil dan menengah evaluasi penggunaan sistem dilakukan baik dengan pengamatan data, penanganan kesalahan (error handling), maupun melalui kuisioner yang diberikan kepada pihak dinas koperasi dan industri kecil dan menengah kota Padang, pelaku industri kecil dan menengah di kota padang juga kepada masyarakat yang ada di kota Padang. Pemberian kuisioner ini bertujuan untuk mendapatkan feedback langsung tentang bagaimana aplikasi dari sistem informasi open data yang telah di bangun. Analisis resiko yang dari awal telah di lakukan di cek lagi baik dari sisi teknik maupun manajemen untuk memastikan sistem informasi dapat digunakan dengan baik. Costumer evaluation ini akan memberikan umpan balik kepada tim peneliti untuk penyempurnaan sistem.

Pada Tahap pertama ini akan dilakukan halhal sebgai berikut :

1. Data primer yang di dapat di bandingkan dengan data sekunder serta data data serta data- data dari BPS tentang industri kecil dan menengah yang ada di kota padang

2. Selanjutnya data tersebut dikelompokan menjadi potensi-potensi industri kecil dan menegah yang ada di kota Padang

3. Selanjutnya data kelompok potensi industri kecil dan menengah berdasarkan jumlah tenaga kerjanya, omset pertahunnya, pendapatan pertahun serta modal yang dimiliki serta konsep pemasaran.

4. Setelah itu peneliti akan merancang tampilan dari sistem informasi open data dengan terlebih dahulu membuat data flow diagram, entity relationship diagram, dan relational diagram serta perancangan data base

5. Untuk keamanan system informasi yang dibuat maka diberikan lah akses untuk operator sistem dan untuk pengguna sistem yaitu masyarakat luas.

Perancangan pada system informasi open data pada industri kecil dan menengah kota Padang di mulai dengan perancangan flowchart system. 
a. Flowchart Sistem Interface Home

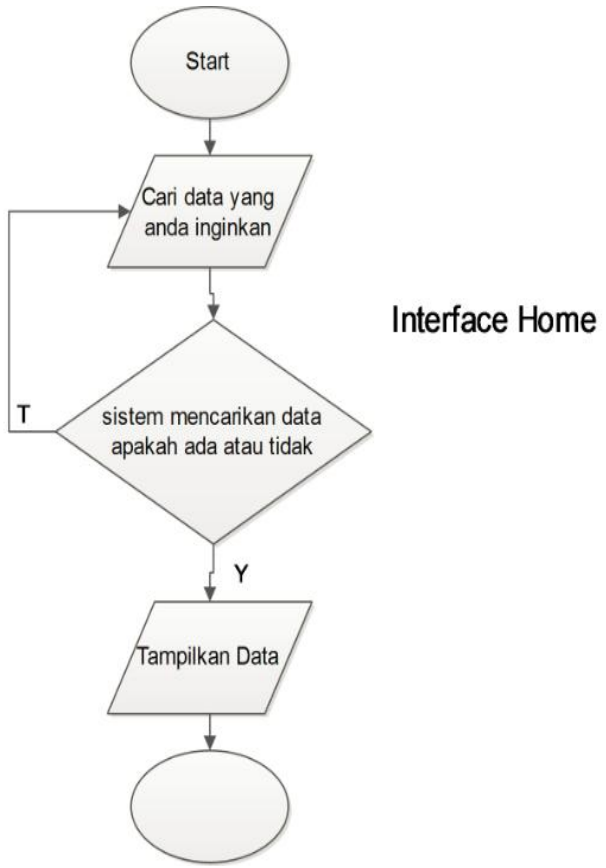

Gambar 3. Flowchar sistem interface home

b. Flowchart Sistem untuk Proses Submit Data

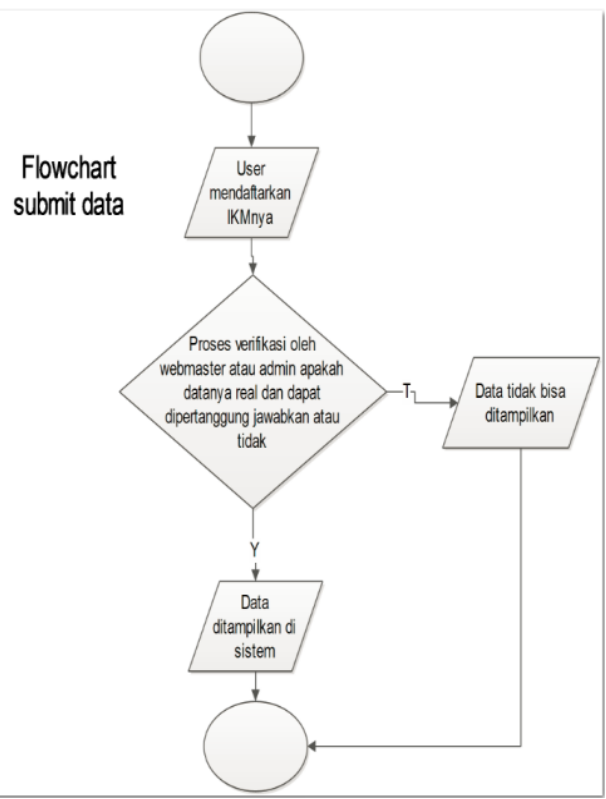

Gambar 4. Flowchart Sistem untuk proses submit data

c. Perancangan Tampilannya berupa perancangan form submit data
Biodata Detall IKM

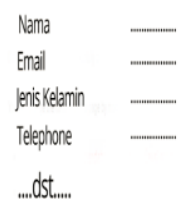

Gambar 5. Perancangan Tampilan Form Submit Data

d. Perancangan Tampilannya berupa perancangan form home

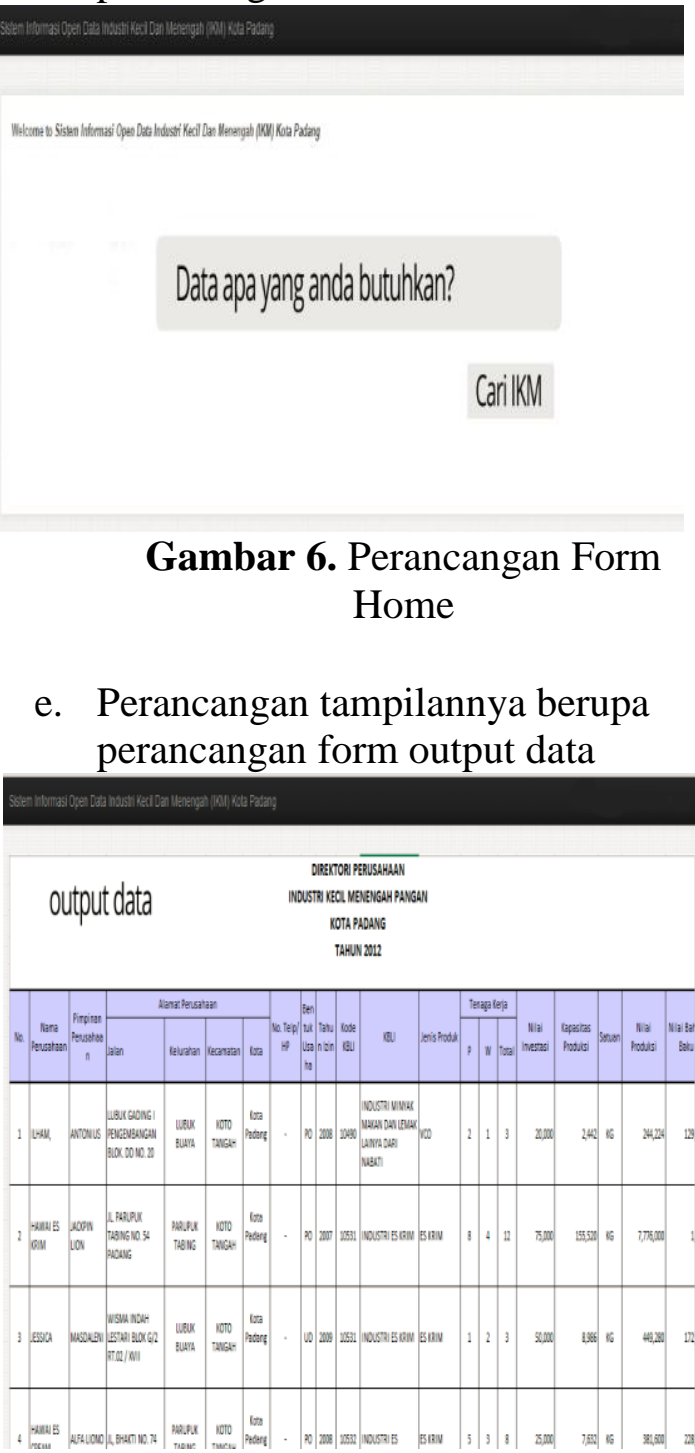

Gambar 7. Perancangan Tampilan Output Sistem Informasi 


\section{HASIL DAN PEMBAHASAN}

Adapaun hasil dari system informasi open data ini adalah :

a. Gambar grafik sebaran ikm berdasarkan kecamatan yang ada di kota padang

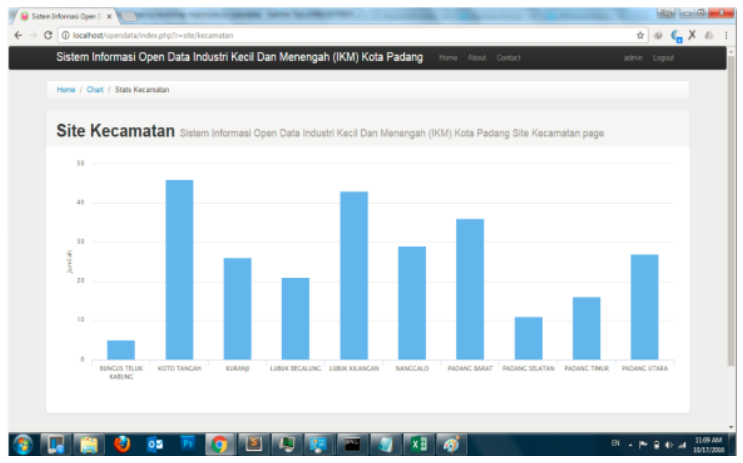

Gambar 8. penyebaran industri kecil dan menengah berdasarkan kecamatan yang ada di kota Padang

b. Gambar list data Industri kecil dan menengah yang ada di kota Padang yang akan dikonfirmasi oleh administrasi system

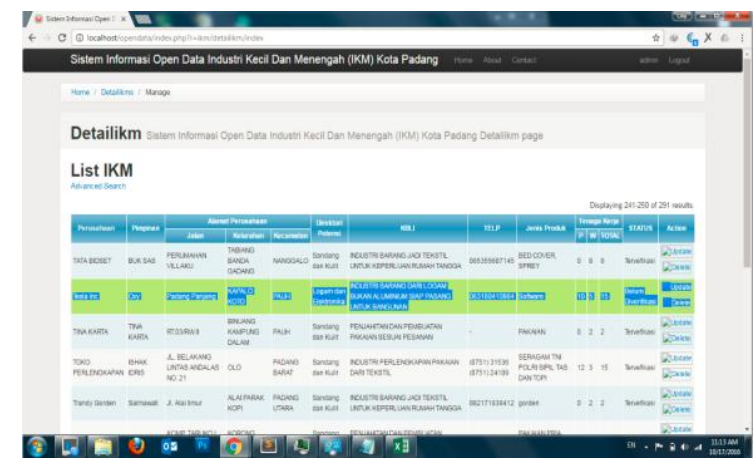

Gambar 9. list data industri kecil dan menengah oleh di kota Padang

c. Gambar form input untuk masyarakat menginputkan industri kecil dan menengah yang mereka punya

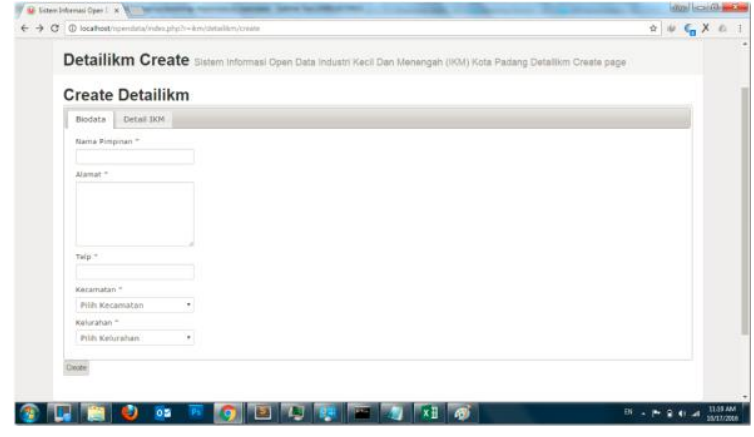

Gambar 10. form input yang dilakukan oleh masyarakat pelaku Industri Kecil dan menengah kota Padang

\section{SIMPULAN}

Adapun kesimpulan dari penelitian ini adalah :

1. Terbentuknya rancangan system informasi berbasis data terbuka untuk data-data industri kecil dan menengah yang ada di kota Padang

2. Sistem Informasi ini menampilkan datadata industri kecil dan menengaha yang ada di kota Padang berbasis web

3. Perancangan system informasi data terbuka ini dapat menjadi acuan bagi pelaku industri kecil dan menengah di kota Padang untuk mendapatkan informasi-informasi yang dapat meningkatkan pendapatan pelaku industri kecil dan menengah itu sendiri

\section{DAFTAR PUSTAKA}

[1] Alexandros Doulamis, Nikos Pelekis, and Yannis Theodoridis. (2012). EasyTracker: An Android Application for Capturing Mobility Behavior. Dept. of Informatics University of Piraeus.

[2] Asit Kumar Parida. (2013). Android Application Development for GPS Based LocationTracker \& NITR Attendance Management System. National Institute of Technology. India

[3] Tambunan, 2003, Perekonomian 
Indonesia menyongsong Abad XXI, Jakarta : Penerbit Pustaka Sinar Harapan

[4] Badan Pusat Statistik, 2011

[5] Biro Pusat Statistik, 2006

[6] Emrizal, 2013, Wirausaha dan Pengembangan UKM di Sumatera Barat : Suatu KAjian Pada UKM Kerajinan Sulaman Dan Bordiran, Polibisnis, Volume 5 No 1 April 2013 Studi Industri Kecil dan Menengah, Departemen Perdagangan Perindustrian Pertambangan dan Energi Bidang Industri Kecil dan Menengah Kota Padang, 2014

[7] Yenida, 2012, kajian Analisis SWOT Terhadap Usaha Industri Kecil dan Rotan Kota Padang, Polibisnis, Volume 4 No.2 Oktober 2012

[8] Komunitas Paseban. (2012). Cara Kerja GPS (Global Positioning System) Pada Ponsel. http://portal.paseban.com/article/1394 1/cara-kerja-gps . tanggal akses 25 April 2014.

[9] OGD Indonesia Final For Publication, https://public.webfoundation.org/201 1/05/OGD_Philipines.pdf

[10] www.selasar.com, Kemana arah Gerakan Open data Indonesia (diakses pada tanggal 18 Maret 2015 )

[11] www.inilahkoran.com, Dorong Investasi dengan Open data : Dari bandung Untuk Indonesia, ( diakses pad tanggal 2 Februari 2015)

[12] www.sinergantara.com, Ekosistem Open data ( diakses pada tanggal :2 Februari 2015) Tutorial Point Team. Software Development Life Cycle. www.tutorialpoint.com tanggal akses 2 April 2015 